Article

\title{
Passing the Test? From Immigrant to Citizen in a Multicultural Country
}

\author{
Elke Winter \\ Faculty of Social Sciences, University of Ottawa, Ottawa, ON K1N 6N5, Canada; E-Mail: elke.winter@uottawa.ca
}

Submitted: 3 April 2018 | Accepted: 15 May 2018 | Published: 30 August 2018

\begin{abstract}
Almost all Western countries have recently implemented restrictive changes to their citizenship law and engaged in heated debates about what it takes to become "one of us". This article examines the naturalization process in Canada, a country that derives almost two thirds of its population growth from immigration, and where citizenship uptake is currently in decline. Drawing on interviews with recently naturalized Canadians, I argue that the current naturalization regime fails to deliver on the promise to put "Canadians by choice" at par with "Canadians by birth". Specifically, the naturalization process constructs social and cultural boundaries at two levels: the new citizens interviewed for this study felt that the naturalization process differentiated them along the lines of class and education more than it discriminated on ethnocultural or racial grounds. A first boundary is thus created between those who have the skills to easily "pass the test" and those who do not. This finding speaks to the strength and appeal of Canada's multicultural middle-class nation-building project. Nevertheless, the interviewees also highlighted that the naturalization process artificially constructed (some) immigrants as culturally different and inferior. A second boundary is thus constructed to differentiate between "real Canadians" and others. While not representative, the findings of this study suggest that the Canadian state produces differentiated citizenship at the very moment it aims to inculcate loyalty and belonging.
\end{abstract}

\section{Keywords}

Canada; citizenship; immigration; integration; interviews; migration; multiculturalism; nation-building; naturalization; qualitative research

\section{Issue}

This article is part of the issue "Migration, Boundaries and Differentiated Citizenship", edited by Terry Wotherspoon (University of Saskatchewan, Canada).

(C) 2018 by the author; licensee Cogitatio (Lisbon, Portugal). This article is licensed under a Creative Commons Attribution 4.0 International License (CC BY).

\section{Introduction}

In early 2014, Zunera Ishaq, a Pakistani national, Sunni Muslim, and permanent resident of Canada was barred from naturalization because she refused to remove her full-face veil (niqab) in public while taking the oath of citizenship. Ishaq was one of the casualties of Stephen Harper's Conservative government's (2006-2015) concerted efforts to "raise and strengthen" the value of Canadian citizenship through a number of administrative and legal measures pertaining to its acquisition, loss, and definition. Under the new mantra, since December 2011, citizenship certificates were to be awarded only to those who would swear allegiance with their faces uncovered in public during the official ceremony. Denouncing the practice of wearing a niqab as "contrary to our own values" (Maccharles, 2015), the Conservative government rejected the possibility for Muslim women to obtain Canadian citizenship by forcing them to unveil themselves for the purposes of security and identity verification in private in front of other women.

Although a federal court struck down the ban on niqabs during citizenship ceremonies and the newly elected Liberal government of Justin Trudeau closed the file in late 2015, the episode demonstrates a development that has become widespread among Western states. So-called "civic integration" policies combine increased emphasis on selection and control of immigrants with measures that insist on their integration before (and as a condition of) citizenship acquisition (Joppke, 2017). Stemming from the Dutch noun inburgering, whose literal English translation would be citizenization or natu- 
ralization, civic integration involves conscious, concerted policy and programming that "condition, incentivize, and shape through socialization immigrants into 'citizens'" (Borevi, Jensen, \& Mouritsen, 2017, p. 1).

During the first years of the 21st century, the paradigm of civic integration spread through Europe, finally reaching the United States, Australia and Canada (Joppke, 2013). In these countries, high naturalization rates - such as those sported by Canada-are no longer interpreted as a self-evident indicator of successful integration. On the contrary, immigrants, especially those from non-Western countries, are increasingly suspected of being unwilling to learn the national language, take up work, and adopt "Western values". They are also said to naturalize "for the wrong reasons", ranging from the abuse of social welfare systems to the use of Western passports for terrorism-related travel. As a consequence, under the paradigm of civic integration, citizenship is increasingly seen as something that needs to be "earned" (Kostakopoulou, 2011).

This article examines the aforementioned policy changes by analyzing the naturalization process-and the nation-building project at its core-from the viewpoint of newly minted citizens in Canada. Granting permanent residence to a substantial number of immigrants (roughly $1 \%$ of its population per year) in an ethnically diverse and normatively multicultural country, the Canadian state has-or should have-a strong interest in allowing the naturalization process to creating feelings of accomplishment, loyalty and belonging within those undergoing it. As mentioned above, Canada recently revised its naturalization procedures in order to protect the integrity and meaningfulness of the naturalization process. While these changes have been studied at the level of policy, discourse, and programming, the perspective of those undergoing the process is rarely heard.

This article contributes to a small but growing body of literature that studies the impact of policy changes under the civic integration paradigm from the views of immigrants and naturalized citizens. It asks the following questions: How welcoming or repelling do new Canadians perceive (different steps of) the naturalization process? How do they relate to the factual and symbolic boundaries at stake in naturalization? My research shows that Canada's current edition of the bureaucratically administered naturalization process fails to create a sense of unity and belonging within those undergoing the process. On the contrary, the new Canadians interviewed in this study expressed concerns over the social and cultural boundaries that they saw as being exacerbated by the naturalization process.

This article is structured as follows: I will first situate my study within the relevant literature and theory. I offer some information on the Canadian context and the empirical research that my argument draws upon. In the main part of the article, I report on new citizens' experiences with the bureaucratic requirements of the naturalization process in Canada. I also discuss the boundaries that emerge from these requirements. I conclude by summarizing my argument.

\section{What is Naturalization?}

Goodman (2014, pp. 2, 229-230) argues that civic integration policies are an iteration of nation-building, which under the condition of ethnic diversity, supplements national identity's emphasis on ethnic sameness by means of a state identity's accentuation of civic togetherness. According to her, states are both "defining new parameters of [collective] belonging under the banner of liberalism", and reinvesting in their formal relationship with the individual, which, in the case of naturalization, is based, at least in principle, on achieved (acquired skill and values) rather than ascribed (ethnic origin) criteria. Goodman's position bridges two diametrically opposed perspectives dominating the literature. One of them claims that citizenship policies have gradually become more liberal (Joppke, 2010), while the other points towards their increasing culturalization (Duyvendak, Geschiere, \& Tonkens, 2016; Orgad, 2016) targeting Muslims in particular (Adamson, Triadafilopoulos, \& Zolberg, 2011).

The means of inculcating this new collective (national/state) identity in newcomers have been studied extensively and controversially. Löwenheim and Gazit (2009, pp. 158-159), most prominently, identify citizenship tests as disciplining, responsibilizing and civilizing tools of state power, which coerce citizenship candidates "to behave in certain ways and conform to certain norms through the threat of punishment". Similarly, Van Oers (2014, pp. 269-272) finds that tests tend to produce frustration and alienation within well-integrated, highly skilled immigrants. By contrast, those struggling to climb up the social ladder within the host society find it harder linguistically and cognitively to assimilate study materials and to perform in the test itself. Other elements of the naturalization process have received more positive evaluations. This is particularly the case for mandatory language courses (Boyd \& Cao, 2009; Extra, Spotti, \& Van Avermaet, 2009) and knowledge requirements, which are seen as fulfilling "an educative or empowering function" by helping immigrants to transition or "journey" towards citizenship acquisition and socio-economic integration (Kiwan, 2008, p. 71).

Whether citizenship study guides (and their corresponding tests) are interpreted as liberal or assimilationist (Michalowski, 2011) seems to vary from country to country, the examined editions, as well as the perspective adopted by the researcher. In international comparisons, citizenship uptake in Canada tends to be evaluated positively, e.g., with respect to high naturalization rates (Bloemraad, 2006), citizenship ceremonies embracing diversity (Byrne, 2014), successful immigrant integration and feelings of belonging (Aptekar, 2014; Bloemraad, 2006), as well as the role of the test within the naturalization process (Paquet, 2012). Comparing the 2009 edition of the Canadian citizenship study guide (produced 
by Harper's Conservative government) to prior editions (in place under Liberal governments), Chapnick (2011) does not find much of a conservative or illiberal shift. Others, by contrast, find the new guide culturally "integrationist" (Blake, 2013), "renationalizing" (Winter \& Sauvageau, 2015), and downplaying existing racism, as well as accusing some newcomers of being culturally and socially backward (Gulliver, 2018).

This article will complement these findings by exposing the view of those having undergone the naturalization process. It adopts an approach that theorizes the process of naturalization as a form of social closure, which involves the drawing (and potential crossing) of symbolic lines-boundaries-between insiders and outsiders.

In principle, the act of naturalization is a rite of passage that lawfully transforms foreigners into full citizens. Naturalization policy is thus the ultimate institutional expression of national boundaries, with citizenship uptake implying a presumably final step of boundary crossing. Defined sociologically, however, citizenship implies more than legal citizenship status. It also involves a set of rights and duties, which can be enjoyed in practice, various forms of participation in a political community, and identity-based membership or "belonging". We may say that belonging describes the symbolic boundaries of citizenship.

This is the level where, for Fassin and Mazouz (2009), the institutionalized ritual of naturalization produces an arbitrary boundary between "citizens by birth" and (naturalized) "citizens by choice". It does so by constructing a dual difference: first, between immigrants who "pass the test" (literally and figuratively) and those who do not; second, between those who are citizens "naturally" by birth ${ }^{1}$ and those who need to be naturalized. According to these authors, the arbitrary symbolic boundaries even between those who "pass the test" and those born into their citizenship are never fully overcome by the ritual. These symbolic boundaries may then turn into social ones, producing identifiable patterns of segregation (Lamont \& Molnár, 2002), and affecting participation, as well as de facto enjoyment of rights even when an individuals' formal citizenship status remains intact. As such, the state seems to produce differentiated citizenship at the very moment and by the very means that it designed to create "civic integration". The title of this article has thus a twofold meaning: not only immigrants have to pass the test; the state as the citizenship granting institution does so too.

\section{Naturalization in Canada}

Since 2005, Canada welcomes roughly 250.000 immigrants (i.e., newcomers with permanent resident status) per year. Until very recently, these individuals have been viewed as "citizens in waiting". Newcomers-coming overwhelmingly from countries of the Global South-are welcomed into an explicitly multicultural country (since 1971), which gives them the sense that their original cultures and languages are valuable contributions to the Canadian way of life. The combination of relatively easy naturalization, multiculturalism, and dual citizenship has been a Canadian trademark for over forty years (Bloemraad, 2006).

Between 2006 and 2015, the Conservative government of Stephen Harper implemented a number of administrative measures, policies, and laws aiming at strengthening the value of Canadian citizenship by making it harder to get and easier to lose (Winter, 2014, 2015). Naturalization requirements were tightened, now insisting on physical presence in the country, the submission of tax reports, additional language tests, and a declaration of the will to reside in Canada. A much more comprehensive citizenship study guide was launched, and the citizenship test rendered more difficult. While policies were softened under the Trudeau Liberals (since 2015), many of the previously implemented "integrity measures" (such as physical presence in the country and the submission of language certificates as part of the citizenship application) have remained untouched (Griffith, 2017). The development of a new citizenship study guide is being debated, but at the point of writing the 2011 edition (Canada, 2011) still advises citizenship candidates against the importation of "barbaric cultural practices" and (ethnic) conflicts from their home countries.

Overall, to be eligible to apply for Canadian citizenship, immigrants must have a permanent resident status, must have legally resided, and have been physically present in the country for three of the previous five years. They must be at least 18 years of age, display an adequate ability in English or French (new documentation/testing is required since November 2012), and have no criminal convictions in the past three years. Undergoing a formal citizenship test, they must understand the rights and responsibilities of citizenship and demonstrate some knowledge of Canadian history, values and institutions. They are also required to take a citizenship oath. Dual citizenship is allowed, thus only immigrants from countries that do not recognize dual citizenship will lose home country citizenship.

While Canada has still one of the highest naturalization rates in the world, the overall rate ${ }^{2}$ fell from $85.6 \%$ in 2011 to $82.7 \%$ in 2016 (Griffith, 2018). Griffith alerts us to the fact that the best predictor of citizenship test pass rates is education. In addition, there is a greater decline in naturalization for immigrants from Asia-for South Asians (mostly Indians and Sri Lankans) mostly for those with lower levels of education, and for East

\footnotetext{
${ }^{1}$ Citizenship by birth refers to both jus sanguinis-citizenship by birth to parents who are members of the polity at stake-and jus soli-citizenship by birth on the polity's soil.

2 The term naturalization rate stipulates how many citizenship certificates are awarded in relation to foreign-born individuals in Canada who are eligible to apply.
} 
Asians (mostly Chinese) across all levels of education (Griffith, 2018, p. 5). Furthermore, naturalization among immigrants in the family class (such as spouses-often women, parents and grandparents) has been declining since 1996.

Alerted by this trend, which accelerated in recent years, a small research team and I conducted interviews with new citizens residing in the Ottawa-Gatineau region (Ontario and Quebec). The analysis in this article is based on 35 one-hour interviews (12 in French and 23 in English) conducted in 2013. Participants were recruited by means of a call for participation through the Institute for Canadian Citizenship and by members of the research team attending citizenship ceremonies in Ottawa with the permission of the Ministry of Immigration, Refugees, and Citizenship Canada (then Citizenship and Immigration Canada). These individuals were part of an immigration cohort that was subjected to a particularly rigorous Canadian-knowledge and language test (in place 20102013). Coding was done inductively for all four administrative steps: the application package/process, the citizenship study guide, the test, and the ceremony.

Three caveats are noteworthy. First, while the findings are not representative, they allow us to better understand-from the perspective of those undergoing the process-whether the current naturalization requirements fulfill the promise of putting "Canadians by choice" at par with "Canadians by birth", as stipulated by Canada's citizenship legislation (Winter \& Madularea, 2018). Second, despite the team's best efforts, highly educated individuals are overrepresented in the sample. While this category corresponds to the type of people that make up the vast majority of (point-system selected) immigrants in Canada, it also means that perspectives from citizenship candidates who are marginalized in Canadian society (i.e. some of those who came as refugees or through family class sponsorships and who, on average, have lower income, less education and lower literacy skills) are potentially missing. The analysis proposed below accounts for this potential bias. Third, in the following analysis, emphasis is placed on the part of the naturalization trajectory that involves dealing with administrative requirements. Defined sociologically, naturalization also involves social, emotional, and symbolic processes over time. ${ }^{3}$ Unfortunately, studying these other dimensions is beyond the scope of this article.

\section{New Citizens' Perspectives on "Passing the Test"}

Drawing upon the interviews conducted by my research team and myself, I will first report on our interviewees' experiences with naturalization requirements in Canada. I will then discuss how the interviewees evaluated these experiences. This discussion will highlight social and so- cioeconomic divisions between those who easily pass the citizenship test, and those who struggle with meeting the requirements for naturalization. Finally, probing for divisions between "Canadians by choice" and "Canadians by birth" will show that cultural biases embedded in the naturalization process draw symbolic boundaries between "real Canadians" and others.

\subsection{Experiences with Naturalization Requirements}

Taken together, there are four steps to the naturalization process in Canada. Immigrants must first submit an application package, then study a sixty-page citizenship guide, take a multiple-choice test, and finally attend a citizenship ceremony. Generally speaking, putting together the application package was considered "a nightmare" (CC12, CC35) ${ }^{4}$ by more than half of the interviewees. Some found the application forms "unclear" (CC32), and some had difficulties obtaining the requested documents from their original countries of citizenship/residence. Almost all complained about the lengthy application process (about 18 months from sending in the application package to the citizenship ceremony). This meant missed job opportunities and loss of revenue for some of the most highly educated interviewees. Others, mostly women and some men from non-Western countries felt unable to travel "back home" where they still had family obligations. They were either unable or uncomfortable travelling on their original travel documents.

Several individuals mentioned that the citizenship fees were quite steep (CAD 100 per person until early 2014; at the time of writing, costs are CAD 530 per person). It was pointed out that costs not only involve naturalization fees, but also travel costs, the need to take vacation from work in order to attend appointments, as well as fees related to photocopies, translations, the certification of documents, etc. Several interviewees also complained about a hostile, anonymous process-where you can never speak to an agent-and about power hierarchies experienced particularly by those less fluent in English.

Experiences related to the citizenship study guide were much more ambiguous. While some enjoyed reading the document, others were appalled (as I will explain in more detail below). The most striking and most frequent observations were the density of information, the high level of English/French necessary to understand the content, as well as the mismatch between the study guide and the citizenship test: "There are things on the test that weren't in the guide, and lots in the guide that's not on the test" (CCO7).

Taking the citizenship was seen as "stressful" (CC05) by some, because the stakes were high and they felt that

\footnotetext{
${ }^{3}$ Naturalization is a process involving the "(im)migration project", the experiences in the receiving society before citizenship acquisition (Bloemraad, 2006), the dealings with civil servants, administrative procedures and the act of naturalization (Fortier, 2017), and the experiences in the receiving society past citizenship acquisition, as naturalization is "also a contract that ties two parties together by a promise", and it is only when this promise is kept that the act of naturalization becomes effective (Fassin \& Mazouz, 2009, p. 61).

${ }^{4}$ Interviews with citizenship candidates are identified by CC, followed by the number of the interview (e.g. CC12).
} 
their citizenship was on the line (CC14). However, only a few claimed that the test's level of difficulty was entirely unreasonable. Much more often, interviewees doubted that the questions asked had any relevance for what is needed in practicing Canadian citizenship: "[The test is] factual and what we need to test is cultural, and how do you test 'cultural'?" (CC13). "[People] study for the exam, then four months later, they'll forget about it. It seems like a hoop you're making people jump through for the sake of....It seems illogical to me rather than essentially serving a purpose" (CC17).

For most of our interviewees, the citizenship ceremony was the most enjoyable part of their administrative naturalization trajectory. Many felt that, by now, they had "passed the test"; they were relieved about this, and eager to celebrate with friends and family. Most were moved by the experience of ethnic diversity at the ceremony, which also tended to be highlighted by the citizenship judge who was welcoming them into the multicultural "Canadian family".

\subsubsection{Interviewees' Own Evaluation}

The notion of equality, suggested by the concept of "family", however, was not the dominant experience by our interviewees during most of the naturalization process. More than half of our interviewees expressed concern over the fact that the application process may have been easy for them but not for others. They felt that the citizenship test "can probably cause difficulties for some people...; if you come here as a skilled worker versus a refugee" (CC12), and especially "if you have somebody where [sic] English is not a prior language. It comes to these minute differences in phrasing, it's kind of cheap" (CC17).

Indeed, many of the highly educated individuals we interviewed found a way to deal with the factual hurdles involved in the naturalization process. For example, frustrated with the slow progress of her application, one citizenship candidate from the United Kingdom explained: "I would put privacy applications in for myself; so, I would put in requests for access to information on myself to get my file" (CC09). Using this government service (mostly used by journalists and researchers) requires confidence, ingenuity, and a high level of familiarity with the Canadian bureaucracy. Another interviewee, originally from the Netherlands, explained how he managed to meet the residence requirement: "I started a sheet keeping track of when I was away with and without my spouse....I kept detailed information [even before the actual citizenship application]" (CC19). While the naturalization process thus does generate some feelings of alienation among better-educated citizenship candidates (e.g., long wait times, meaninglessness), as Löwenheim and Gazit (2009) maintain, due to their education and professional experiences, these individuals already possessed-or quickly acquired-the bureaucratic mindset that is necessary to successfully overcome factual hurdles.
Furthermore, they were fully aware of being part of a nation-building project stressing professional skills, education, and the creation of a "performance-based" Canadian citizenry:

I think [the test is] good. I think probably only for myself because I'm literate. I can read, I can study. I took a lot of exams in China so I'm good at it. I'm thinking that if there are some people who are not very literate that they [may] have difficulty in learning or reading and [if] they don't understand English at all or French at all whether they'll have problems. (CC18)

Similarly, a former international student from Columbia explains:

The test itself wasn't difficult for me, but l'm someone who's been in academia for a really long time so I'm used to taking tests. I'm wondering how hard the test is for people who don't have the time to study and haven't passed tests in a really long time. It must not be very easy. (CC24)

In both quotes, the interviewees express strong confidence in their skills and high level of education. The aforementioned interview with a new Canadian citizen from China demonstrates this quite clearly. As our interviewee put it: "I knew for sure I will get it [Canadian citizenship] because I'm qualified, right?" (CC18). Notably, both quotes also stem from individuals who self-identify as members of "visible minority" groups. Indeed, in our study, class-based differences between citizenship candidates were identified as being more prevalent than cultural or "racial" boundaries between citizenship candidates and "Canadians by birth". Only very few of the interviewees expressed concerns over racism or the existence of a glass ceiling within Canadian society. Rather, rightly or wrongly, for many of the highly skilled new Canadians, regardless of their cultural, racial or ethnic background, naturalization felt like crossing a blurred boundary: it catapulted them right into the Canadian multicultural middle-class.

\section{2. "Canadians by Choice" or "Canadians by Birth": The Cultural Biases}

On the one hand, our study suggests that those who possess the skillset to overcome the factual hurdles of the naturalization process are confident that potential symbolic boundaries are either not existent or can be overcome in the long run. This view is facilitated by Canada's multiculturalism, which captures the ethos of the civil rights revolution and, increasingly, market liberalization (Kymlicka, 2013). On the other hand, not all of our interviewees were able or willing to "laugh off" naturalization requirements that they considered to be ethnocentric and culturally condescending. Roughly a quarter of our interviewees stated feeling uneasy about the citizenship 
study guide, the "Canadian values" that it uncritically portrays as "real", and the social divisions within Canadian society that it glances over. The following quote exemplifies this discomfort most vigorously with respect to the "Canadian value" of gender equality: "I was intensely offended by some of [the citizenship guide] where there'd be like 'Canadians don't abuse women'. A) That's not true. B) Who the hell do you think you're writing for, a bunch of simpletons?" (CC32). It is telling that this quote is not from a Muslim, a group that is widely seen as being the target of this kind of rhetoric (Winter \& Previsic, 2017). Rather, it stems from a Christian who came from Bulgaria to Canada as a spouse. According to her:

The cultural biases [in the guide] were strong. It treated potential citizens as simultaneously unable to understand basic concepts like 'We don't hurt women'. It didn't say we don't hurt women. It said women are full part of our society, blah blah blah....But they put it down in a vaguely condescending way. (CC32)

The cultural biases towards new Canadians from certain countries and religions were also detected in the citizenship ceremony. About one third of the interviewees commented on the fact that officers were checking lip movements during the sermon. Many brushed it off as "really dumb" (CC12), but others called it "disturbing" (CC32). While none of our interviewees was wearing a full-face veil and hence did not suffer the same fate as Zunera Ishaq, many felt the same scrutiny while reciting the oath of citizenship. Tellingly, in our sample, only individuals who did not self-identify as Muslim or "visible minority" commented on lip checking at the ceremony. We may thus only guess how difficult this experience is for those who feel directly targeted by this practice.

Overall, the promise of blurred boundaries and full citizenship based on (economic) merit that some of our professionally successful interviewees said they experienced (especially when comparing their own fate to that of the less educated) seems to be somewhat cast in doubt by these observations. While the Canadian naturalization process seems to come close to overcoming the symbolic boundaries between those who pass the test easily-namely highly skilled and highly educated individuals independently of their ethnocultural background-and "Canadians by birth", it also seems to be incapable of eliminating these boundaries fully. On the contrary, some elements of the naturalization process actively produce differentiated citizenship both within the group of newcomers undergoing naturalization, as well as between new Canadians of certain ethnocultural backgrounds on the one hand, and, on the other, "old stock" Canadians, as the former Canadian Prime Minister Stephen Harper notoriously called them (Edwards, 2015).

\section{Conclusions}

In this article, I examined new citizens' experiences with the bureaucratic requirements of the naturalization process in Canada. Being a self-proclaimed nation of immigrants, Canada's citizenship law has long been designed to put "Canadians by choice" on par with "Canadians by birth". The state therefore has-or should have-a strong interest in designing and implementing a naturalization process that allows permanent residents to join the Canadian citizenry as equal members, and that eliminates the creation or perpetuation of ascribed (symbolic) differences between insiders and outsiders. This interest is - or should be-reinforced by the fact that Canada, like other Western states, has recently redesigned its naturalization requirements as part of a concerted state effort to create a new form of "civic togetherness" (Goodman, 2014).

Drawing on interviews with recently naturalized Canadians, I argued that the current naturalization regime fails to fully deliver on these promises. My research complements studies that find Canada's new citizenship regime integrationist (Blake, 2013), renationalizing (Winter \& Sauvageau, 2015), and discriminating (Gulliver, 2018). While the Canadian naturalization regime does, to a certain extent, redefine collective belonging based "on achieved (acquired skill and values) rather than ascribed (e.g., ethnic origin) criteria", as claimed by Goodman's thesis (Goodman, 2014, pp. 2, 229-230), the individuals interviewed in this study did not experience the naturalization process as unifying or creating "togetherness". On the contrary, they were acutely aware of-and raised concerns about - the social and cultural boundaries constructed by the naturalization processand this at two levels. First, the strong emphasis on professional skills, language competences, and education in the naturalization process reproduces the kind of economic selection that is already prevalent in Canada's immigration regime, the point system. New citizens felt that they were differentiated (again) along the lines of class and education. If their impressions are valid, even in Canada the naturalization process creates a boundary between those who (easily) "pass the test" and those who do not (Fassin \& Mazouz, 2009). Given that naturalization correlates with higher income (Griffith, 2018; Pendakur \& Bevelander, 2014), this design of the naturalization requirements produces not equal but differentiated citizenship. "Failed" or "delayed" citizens with low education levels are here at the bottom of society, while those able to market their skills-and Canadian citizenship-move to the top. Second, the fact that the new citizens we interviewed found class/education differences between citizenship candidates to matter more than differences based on ethnic/national background (either between citizenship candidates or between the latter and Canadian society) points to the strength and appeal of Canada's multicultural nation-building project. This is an important finding that should not be neglected. 
Nevertheless, the promise of full citizenship is marred when citizenship candidates feel treated in culturally condescending ways. Some of our interviewees reacted sharply to a citizenship study guide that lays blame for social conflict upon (some) immigrants' presumed cultural backwardness. Some also felt disaffected by the intense scrutiny of lip movement while performing the oath of citizenship. In such instances, naturalization does indeed not put (naturalized) "citizens by choice" on par with "citizens by birth". On the contrary, as Fassin and Mazouz (2009) point out, citizenship candidates-having lived for years in the country paying taxes and without having a criminal record-find themselves confronted by an institutionalized ritual that artificially constructs them as "different". The state produces differentiated citizenship at the very moment it claims to inculcate "civic togetherness".

\section{Acknowledgments}

This article was written during a Fellowship at the Institute for Advanced Study, Centre of Excellence Cultural Foundations of Integration, University of Konstanz, Germany. The author expresses her gratefulness to the Institute for Canadian Citizenship and to the Ministry of Immigration, Refugees and Citizenship Canada for facilitating the empirical parts of this research. She gladly acknowledges research funding received from the Social Sciences and Humanities Research Council of Canada. Many thanks to the participants in this study, as well as to the students and research assistants without whom this research would not have been possible, most notably Marie-Michèle Sauvageau and Adina Madularea. Finally, thanks also to Jocelyn Kane at the Canadian Centre on Statelessness.

\section{Conflict of Interests}

The author declares no conflict of interests.

\section{References}

Adamson, F. B., Triadafilopoulos, P., \& Zolberg, A. R. (2011). The limits of the liberal state: Migration, identity and belonging in Europe and the United States. Journal of Ethnic \& Migration Studies, 37(6), 843-859.

Aptekar, S. (2014). Citizenship Status and patterns of inequality in the United States and Canada. Social Science Quarterly, 95(2), 343-359.

Blake, R. B. (2013). A new Canadian dynamism? From multiculturalism and diversity to history and core values. British Journal of Canadian Studies, 26(1), 79-103.

Bloemraad, I. (2006). Becoming a citizen in the United States and Canada: Structured mobilization and immigrant political incorporation. Social Forces, 85(2), 667-695.
Borevi, K., Jensen, K. K., \& Mouritsen, P. (2017). The civic turn of immigrant integration policies in the Scandinavian welfare states. Comparative Migration Studies, 5(9), 14. https://doi.org/10.1186/s40878-0170052-4

Boyd, M., \& Cao, X. (2009). Immigrant language proficiency, earnings, and language policies. Canadian Studies in Population, 36(1/2), 63-86.

Byrne, B. (2014). Making citizens: Public rituals and personal journeys to citizenship. Basingstoke, NY: Palgrave Macmillan.

Canada. (2011). Discover Canada: The rights and responsibilities of citizenship. Ottawa: Minister of Public Works and Government Services Canada. Retrieved from www.cic.gc.ca/english/pdf/pub/discover.pdf

Chapnick, A. (2011). A "Conservative" national story? The evolution of citizenship and immigration Canada's discover Canada. American Review of Canadian Studies, 41(1), 20-36.

Duyvendak, J. W., Geschiere, P., \& Tonkens, E. (Eds.). (2016). The culturalization of citizenship: Belonging and polarization in a globalizing world. London: Palgrave Macmillan.

Edwards, P. (2015). 'Old stock Canadians' comment gives chills to professor. Toronto Star. Retrieved from www.thestar.com/news/canada/2015/09/18/ old-stock-canadians-phrase-chills-prof-ignites-twitter. html

Extra, G., Spotti, M., \& Van Avermaet, P. (Eds.). (2009). Language testing, migration and citizenship: Crossnational perspectives on integration regimes. London: Continuum.

Fassin, D., \& Mazouz, S. (2009). What is it to become French? Naturalization as a Republican rite of institution. Revue française de sociologie, 5(50), 37-64.

Fortier, A.-M. (2017). The social life of citizenisation and naturalisation: Outlining an analytical framework. COLLeGIUM: Studies Across Disciplines in the Humanities and Social Sciences, 23(1), 12-30.

Goodman, S. W. (2014). Immigration and membership politics in Western Europe. Cambridge: Cambridge University Press.

Griffith, A. (2017). The evolution of citizenship: Policy, program and operations (Part III). The Canadian Immigration Historical Society Bulletin, 80, 7-12.

Griffith, A. (2018). What the census tells us about citizenship. Policy Options. Retrieved from policyoptions.irpp.org/magazines/march-2018/what -the-census-tells-us-about-citizenship

Gulliver, T. (2018). Canada the redeemer and denials of racism. Critical Discourse Studies, 15(1), 68-86. https://doi.org/10.1080/17405904.2017.1360192

Joppke, C. (2010). Citizenship and immigration. Cambridge: Polity.

Joppke, C. (2013). Through the European looking glass: Citizenship tests in the USA, Australia and Canada. Citizenship Studies, 17(1), 1-15.

Joppke, C. (2017). Civic integration in Western Eu- 
rope: Three debates. West European Politics, 40(6), 1153-1176. https://doi.org/10.1080/01402382. 2017.1303252

Kiwan, D. (2008). A journey to citizenship in the United Kingdom. International Journal on Multicultural Societies (UNESCO), 10(1), 60-75.

Kostakopoulou, D. (2011). Citizenship, identity and immigration in the European Union: Between past and future. Manchester: Manchester University Press.

Kymlicka, W. (2013). Neoliberal multiculturalism. In P. A. Hall \& M. Lamont (Eds.), Social resilience in the neoliberal era (pp. 99-125). Cambridge: Cambridge University Press.

Lamont, M., \& Molnár, V. (2002). The study of boundaries in the social sciences. Annual Review of Sociology, 28(1), 167-195. https://doi.org/10.1146/ annurev.soc.28.110601.141107

Löwenheim, O., \& Gazit, O. (2009). Power and examination: A critique of citizenship tests. Security Dialogue, 20(2), 145-167.

Maccharles, T. (2015). Face-covering veils are 'antiwomen', Harper says. Toronto Star. Retrieved from www.thestar.com/news/canada/2015/03/10/ stephen-harper-dismisses-trudeaus-charge-of-divid ing-country.html

Michalowski, I. (2011). Required to assimilate? The content of citizenship tests in five countries. Citizenship Studies, 15(6/7), 749-768.

Orgad, L. (2016). The cultural defense of nations: A liberal theory of majority rights. Oxford: Oxford University Press.

Paquet, M. (2012). Beyond appearances: Citizenship tests in Canada and the UK. Journal of International Migration and Integration, 13(2), 243-260.

Pendakur, R., \& Bevelander, P. (2014). Citizenship, enclaves and earnings: Comparing two cool countries. Citizenship Studies, 18(3/4), 384-407. https:// doi.org/10.1080/13621025.2014.905279

Van Oers, R. (2014). Deserving citizenship: Citizenship tests in Germany, the Netherlands and the United Kingdom. Leiden: Martinus Nijhoff Publishers.

Winter, E. (2014). Becoming Canadian: Making sense of recent changes to citizenship rules. Montreal Institute for Research on Public Policy, 44, 1-28. Retrieved from www.irpp.org/en/research/diversityimmigration-and-integration/becoming-canadian

Winter, E. (2015). Report on citizenship law: Canada. Florence: Euroean University Institute. Retrieved from eudo-citizenship.eu/country-profiles/?country =Canada

Winter, E., \& Madularea, A. (2018). Quo vadis Canada? Tracing the contours of citizenship in a multicultural country. In S. Guo \& L. Wong (Eds.), Immigration, racial and ethnic studies in 150 years of Canada: Retrospects and prospects (pp. 191-208). Leiden: Brill.

Winter, E., \& Previsic, I. (2017). Citizenship revocation in the mainstream press: A case of re-ethnicization? Canadian Journal of Sociology, 41(1), 55-82.

Winter, E., \& Sauvageau, M.-M. (2015). Vers une compréhension nationaliste de la naturalisation au Canada? Analyse des changements récents en matière d'octroi de la citoyenneté dans le contexte canadien. La Revue canadienne Droit et Société, 30(1), 73-90.

\section{About the Author}

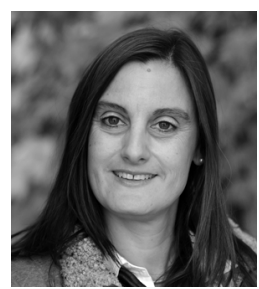

Elke Winter is Professor of Sociology at the University of Ottawa, a Fellow at the University of Konstanz' Institute for Advanced Study (in 2017-2018), as well as an Alexander von Humboldt Research Fellow (in 2018-2020). She currently pursues a two-legged research agenda. A first set of projects concentrates on refugee integration in Germany and Canada. A second set of research projects deals with citizenship acquisition and loss in Canada, Germany and France. For details see http://elkewinter.com. 